\title{
The effect of service quality and customer satisfaction toward customer loyalty in service industry
}

\author{
Dewi $^{a}$, Ferdian Hajadi ${ }^{a}$, Yunita Wijaya Handranata ${ }^{a}$ and Maria Grace Herlina ${ }^{b^{*}}$
}

a Business Creation Program, BINUS Business School, Bina Nusantara University, Jakarta, Indonesia ${ }^{b}$ Management Program, BINUS Business School, Bina Nusantara University, Jakarta, Indonesia

\begin{tabular}{|c|c|}
\hline CHRON I C LE & A B S T RA C T \\
\hline $\begin{array}{l}\text { Article history: } \\
\text { Received January } 25,2021 \\
\text { Received in revised format } \\
\text { January, } 26,2021 \\
\text { Accepted May } 182021 \\
\text { Available online } \\
\text { May } 182021 \\
\text { Keywords: } \\
\text { Service Quality } \\
\text { Customer Satisfaction } \\
\text { Customer Loyalty }\end{array}$ & $\begin{array}{l}\text { The purpose of this study is to determine the impact of service quality and customer satisfaction } \\
\text { on customer loyalty of the laundry service industry in Indonesia. The research methods used } \\
\text { were quantitative, and analyzed using multiple linear regression methods. Data were obtained by } \\
\text { distributing questionnaires to } 100 \text { respondents in Jakarta from February to March } 2020 \text {. The } \\
\text { selection of respondents used a purposive sampling technique, with the criteria of using laundry } \\
\text { services in the past. Findings from this research revealed a significant positive effect of service } \\
\text { quality toward customer satisfaction; and both service quality and customer satisfaction also have } \\
\text { significant and positive effects towards customer loyalty in laundry services in Indonesia. From } \\
\text { this research, it is expected that the entrepreneur in the laundry service industry would better } \\
\text { understand the importance of service quality, customer satisfaction and its correlation to } \\
\text { customer loyalty in order to improve firm sales performance. }\end{array}$ \\
\hline
\end{tabular}

\section{Introduction}

In this era, modern society with a fast-paced lifestyle and high mobility, makes people not have much time to do simple routines such as washing clothes. This lifestyle attitude is a character of generation $\mathrm{z}$ and millennial (IDN, 2020). This lifestyle change makes people choose a fast and simple solution by using laundry services to wash their daily clothes, making this laundry service an ideal new business opportunity. The laundry service industry has low entry barriers, resulting in tight and massive laundry business competition. Therefore, to stay in business, companies must provide the best experience for their services through quality service, and customer satisfaction to earn customer loyalty to be able to increase and maintain sales and business growth (Purba et al., 2016). Moreover, research on the impact of service quality and customer satisfaction on customer loyalty has been widely studied in many industries such as culinary industry (Rashid et al., 2015) and telecommunications industry (Akbar \& Parvez, 2009) but, research in the laundry service industry is still very limited. Hence, further research is needed in order to analyze the impact and relationship between service quality, customer satisfaction and customer loyalty in the laundry service industry.

\section{Literature review}

\subsection{Service quality}

In conducting business in the service industry, it is very important to study the concept and to understand the results of service quality (Rauch et al., 2015). According to (Parasuraman et al., 1988), there are 5 (five) dimensions of service quality, namely: tangibles, reliability, responsiveness, assurance, and empathy. Today, many service companies recognize the

\footnotetext{
* Corresponding author

E-mail address: herlina01@binus.edu (M. G. Herlina)

(C) 2021 by the authors; licensee Growing Science. doi: $10.5267 /$ j.uscm.2021.5.007
} 
importance of quality of service, which will result in customer satisfaction and loyalty. Good service quality will have an impact on customer satisfaction, which will ultimately have a positive impact on brand value and better financial performance (Lam et al., 2011). The correlation between service quality and customer satisfaction is still being debated (Saad Andaleeb \& Conway, 2006). Some previous research found that service quality does not have impact correlation with customer satisfaction (Kristanto, 2018; Parasuraman et al., 1985). In contrast, other results in previous research found that variable service quality has a positive correlation with customer satisfaction (Liang \& Zhang, 2009; Sureshchandar et al., 2002). Moreover, providing good service quality on a continuous basis will also generate high customer loyalty to the company (Chomvilailuk \& Butcher, 2014). This is in line with the research conducted by (Davis-Sramek et al., 2009), who found that service quality has a significant positive effect on customer loyalty. On the other hand, research conducted by (Lee \& Kao, 2015) found that service quality has a positive but not significant effect on customer loyalty. Hence, from the results of the description above, we propose the following hypothesis:

$\mathbf{H}_{1}$ : Service quality has a significant and positive effect toward customer satisfaction in laundry services in Indonesia.

$\mathbf{H}_{2}$ : Service quality has a significant and positive effect toward customer loyalty in laundry services in laundry services in Indonesia.

\subsection{Customer satisfaction}

Customer satisfaction is a very important factor to build customer loyalty. This is supported by several past research, such as: (Wirtz et al., 2012); Griffin (1995); Hill \& Alexander (2006); Oliver (1997); and Vandermerwe (1996). On the other hand, there are also a number of contradictory studies showing that high loyalty is not always influenced by customer satisfaction (Oliver, 1999; Seiders et al., 2005). Therefore, additional verification should be performed to determine whether or not there is a correlation between quality of service and customer loyalty in the laundry services industry. Thus, hypothesis 3 is stated as follow,

H3: Customer satisfaction has a significant and positive effect toward customer loyalty in laundry services in Indonesia.

The research model is shown in Fig. 1.

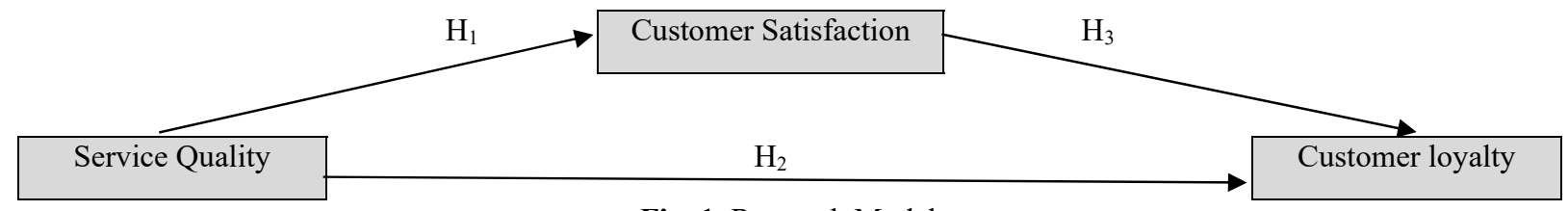

\section{Methodology}

Fig. 1. Research Model

The research method used in this research is quantitative analysis. The research process begins with the preparation of a questionnaire based on previous research conducted by Irawan et al. (2018) with 19 questions, measured on a 5-point Likert scale ranging from strongly disagree (score 1) to strongly agree (score 5). In addition, the chosen regions in this study is Jakarta, because it has a large population of $\mathrm{z}$ generation with 3.18 million people and millennial generation with 3 million people (BPS, 2017). The questionnaires distributed via online by Google Form, and the selection of respondents used a purposive sampling technique, with the criteria of having used laundry services in the past. Data obtained by distributing questionnaires to 100 respondents in February - March 2020. Finally, the data results were processed using Regression Multiple Linear method and analyzed using Statistical Package for the Social Sciences program (SPSS) version 20.

\section{Results and discussion}

We first present details of the personal characteristics of the participants in this survey which are given in Fig. 2 as follows,

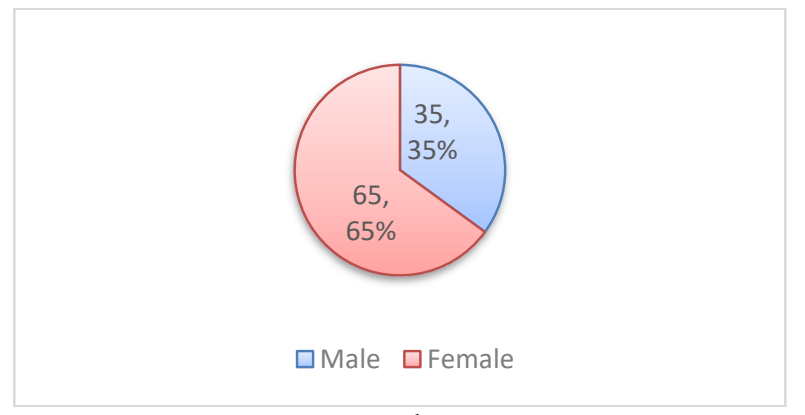

Gender

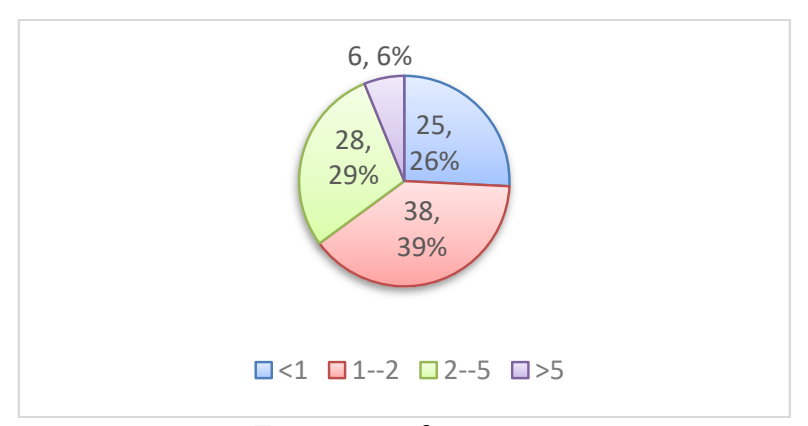

Frequency of response

Fig. 2. Personal characteristics of the participants 
According to Fig. 2, it can be seen that respondents in this study were dominated by women with a percentage of $65 \%$ of the total sample. Also, the figure shows the frequency of respondents using laundry services in a month, with the highest value $1-2$ times a month (38\%), followed by $3-5$ times a month $(28 \%),<1$ time a month $(25 \%)$, and $>6$ times a month (6\%).

Validity tests were conducted to determine whether the questionnaires were valid and reliable. The process counting system by correlating each question and score, with the Pearson Correlation technique. The basis for decision making in this validity test are: if the $\mathrm{R}$ value $>\mathrm{R}$ table, then the statement is valid, whereas if $\mathrm{R}$ value $<\mathrm{R}$ table, then the statement is invalid. For the basis decision making in the reliability test are: if Cronbach's alpha value $>0.60$ is considered reliable, if Cronbach's alpha $<0.60$ it is considered unreliable. The following is attached with the results given in Table 1.

Table 1

Validity Test

\begin{tabular}{|c|c|c|c|c|}
\hline Variable & Item & R value & R table & Test Results \\
\hline \multirow{10}{*}{ Service Quality } & SQ1 & 0.407 & 0.196 & Valid \\
\hline & SQ2 & 0.523 & 0.196 & Valid \\
\hline & SQ3 & 0.558 & 0.196 & Valid \\
\hline & SQ4 & 0.492 & 0.196 & Valid \\
\hline & SQ5 & 0.628 & 0.196 & Valid \\
\hline & SQ6 & 0.675 & 0.196 & Valid \\
\hline & SQ7 & 0.550 & 0.196 & Valid \\
\hline & SQ8 & 0.432 & 0.196 & Valid \\
\hline & SQ9 & 0.410 & 0.196 & Valid \\
\hline & SQ10 & 0.617 & 0.196 & Valid \\
\hline \multirow{5}{*}{$\begin{array}{c}\text { Customer } \\
\text { Satisfaction }\end{array}$} & CS1 & 0.752 & 0.196 & Valid \\
\hline & $\mathrm{CS} 2$ & 0.717 & 0.196 & Valid \\
\hline & CS3 & 0.710 & 0.196 & Valid \\
\hline & CS4 & 0.686 & 0.196 & Valid \\
\hline & CS5 & 0.730 & 0.196 & Valid \\
\hline \multirow{4}{*}{ Customer Loyalty } & CL1 & 0.727 & 0.196 & Valid \\
\hline & CL2 & 0.672 & 0.196 & Valid \\
\hline & CL3 & 0.710 & 0.196 & Valid \\
\hline & CL4 & 0.794 & 0.196 & Valid \\
\hline
\end{tabular}

Table 2

The summary of the reliability test

\begin{tabular}{cccc}
\hline Variable & Cronbach's Alpha & Cut Off & Description \\
\hline Service Quality & 0.710 & 0.60 & Reliable \\
Customer Satisfaction & 0.766 & 0.60 & Reliable \\
Customer Loyalty & 0.677 & 0.60 & Reliable \\
\hline
\end{tabular}

Based on the Table 1 and Table 2, it can be concluded that all questions on the questionnaires are valid and reliable. The coefficient of determination can be interpreted as the effect on the dependent variable, given by the independent variable. The results are given in Table 3 as follows,

Table 3

The results of R-Square

\begin{tabular}{cc} 
Coefficient of Determination & R-Squares \\
\hline Service quality $\rightarrow$ customer satisfaction & 0.438 \\
Service quality and customer satisfaction $\rightarrow$ customer loyalty & 0.235 \\
\hline
\end{tabular}

Table 5 shows that the value of R-Squares of service quality toward customer satisfaction is 0.438 or $43.8 \%$ and the rest of $56.2 \%$ is explained by the other variables. The result of R-Squares of service quality and customer satisfaction toward customer loyalty is 0.235 or $23.5 \%$ and the rest of $76.5 \%$ from other variables which are not explained in this research. In this study, hypothesis testing uses two-tailed T-statistical calculations with a significance of $95 \%$, from the result of Tstatistic value. The basis of decision making is if significance $<0.05$ then the statement is significant, and whereas if the significance $>0.05$ then the statement is insignificant. Table 4 presents details of the results of testing the hypotheses.

Table 4

The results of testing of different hypotheses

\begin{tabular}{ccccl}
\hline Hypothesis Test & T Value & Sig 95\% & Sig & Description \\
\hline Service Quality $\rightarrow$ Customer Satisfaction & 8.746 & 1.984 & 0.000 & Positive, Significant \\
Service Quality $\rightarrow$ Customer Loyalty & 2.143 & 1.984 & 0.035 & Positive, Significant \\
Customer Satisfaction $\rightarrow$ Customer Loyalty & 2.343 & 1.984 & 0.021 & Positive, Significant \\
\hline
\end{tabular}


Table 6 shows that the results of service quality on customer satisfaction found that the t- value of 8.746 with a significance level of 0.000 , and the significance level less than 0.05 . This indicates that the service quality has a positive and significant effect on customer satisfaction in laundry services in Indonesia, and it shows that the hypothesis is supported. The results of service quality on customer loyalty shows that the t-value of 2.143 with a significance level of 0.035 , less than 0.05 . So, the service quality has a positive and significant effect on customer loyalty in laundry services in Indonesia. Based on calculation results, the customer satisfaction with t-value of 2.343 and significance level of 0.021 , which indicates the customer satisfaction has a positive and significant effect on customer loyalty in laundry services in Indonesia.

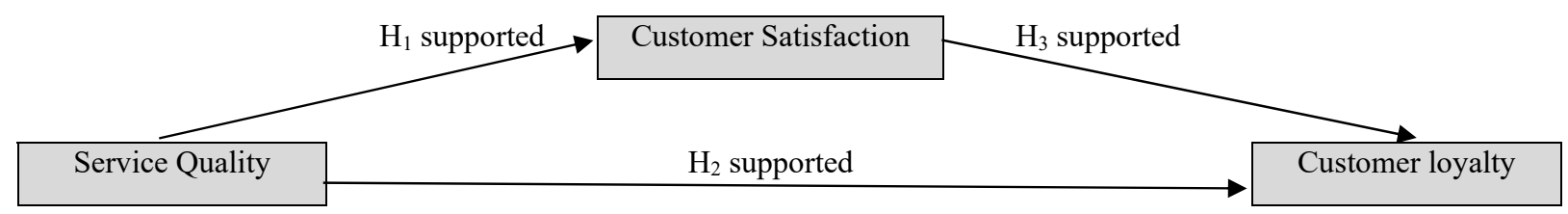

Fig. 2. The results of testing the hypotheses

\section{Discussion}

H1: Service quality has significant and positive effects toward customer satisfaction in laundry services in Indonesia.

From the results of the study, we have found that the service quality had a significant and positive effect on customer satisfaction in laundry services in Indonesia, and this result is consistent with the results of the previous research from (Irawan et al., 2018; Rusmawati \& Marlindawaty, 2018) which says that service quality has a significant and positive effect on customer satisfaction. Furthermore, the higher the service quality, the level of customer satisfaction is also increasing.

\section{$\mathbf{H}_{2}$ : Service quality has significant and positive effects toward customer loyalty in laundry services in Indonesia.}

Based on the results of the study, the service quality has significant and positive effect on customer loyalty in laundry services in Indonesia, and being conformity with the previous research from (Lee \& Kao, 2015; Nurcahyo \& Nurtjahjani, 2018 ) the service quality has a significant and positive effect on customer loyalty. Additionally, the service quality is very important in the services industry, in order to obtain customer loyalty.

\section{H3: Customer satisfaction has significant and positive effects toward customer loyalty in laundry services in Indonesia.}

Based on the results of the study, we have found that the variable of customer satisfaction has a significant and positive effect on customer loyalty in laundry services in Indonesia. The test result is in line with the results of the previous research from (Harumi, 2016; Leninkumar, 2017) which says that customer satisfaction has a significant and positive effect on customer loyalty. Furthermore, providing good customer satisfaction will make an impact on customer loyalty growth.

\section{Conclusion}

Hence, the conclusion of this research are summarized as follows,

1. From the results of this study, service quality has a significant and positive effect on customer satisfaction in laundry services. Moreover, a better service quality gives added value to customer satisfaction in Indonesia.

2. From the results of this study, customer satisfaction has a significant and positive effect on customer loyalty in laundry services. Moreover, a better customer satisfaction gives added value to customer loyalty in Indonesia.

3. From the results of this study, service quality has a significant and positive effect on customer loyalty in laundry services. Moreover, improving service quality increases the value of customer loyalty growth in Indonesia.

This research is expected to be useful and beneficial for laundry practitioners or those who want to enter the laundry industry, so they can get more information about the laundry industry. However, this study suffers from limited resources, the research only focuses on the effect of service quality and customer satisfaction on customer loyalty in the laundry service industry. With the limited variables in this study there are still many factors that have an effect on customer loyalty such as laundry location, price offer, and promotion. Meanwhile, the number of samples in this study which is only 100 samples makes the answers limited by respondents, it would be better if you get more samples so that you get wider and more diverse results. 


\section{References}

Akbar, M. M., \& Parvez, N. (2009). Impact of Service Quality, Trust, and Customer Satisfaction on Customer Loyalty. ABAC Journal, 29(1), 24-38.

BPS. (2017, September 10). Berapa Jumlah Penduduk Jakarta? Databoks.Katadata.Co.Id. https://databoks.katadata.co.id/datapublish/2018/01/24/berapa-jumlah-penduduk-jakarta\#

Chomvilailuk, R., \& Butcher, K. (2014). Effects of quality and corporate social responsibility on loyalty. Service Industries Journal, 34(11), 938-954. https://doi.org/10.1080/02642069.2014.915952

Davis-Sramek, B., Droge, C., Mentzer, J. T., \& Myers, M. B. (2009). Creating commitment and loyalty behavior among retailers: What are the roles of service quality and satisfaction? Journal of the Academy of Marketing Science, 37(4), 440-454. https://doi.org/10.1007/s11747-009-0148-y

Harumi, S. D. (2016). Pengaruh Kepercayaan Dan Kepuasan Pelanggan Terhadap Loyalitas Pelanggan Di Perusahaan Seiko Laundry Medan. Analitika, 8(2), 115-128. http://ojs.uma.ac.id/index.php/analitika

IDN. (2020). Indonesia Millennial Report. IDN Research Institute, $01, \quad 61$. https://www.idntimes.com/indonesiamillennialreport2019

Irawan, F., Suganda, G., \& Bernarto, I. (2018). The Influence of Service Quality and Customer Satisfaction toward Customer Loyalty. International Conference in Innovative Business and Entrepreneurship, 3, $149-159$. http://www.thaiejournal.com

Kristanto, J. (2018). Pengaruh Kualitas Layanan, Kualitas Produk, Dan Harga Terhadap Kepuasan Pelanggan Di Cafe One Eighteenth Coffee. Agora, 6(1), 287217.

Lee, Y.-J., \& Kao, P.-H. (2015). Effects of Service Quality on Customer Loyalty-A Case of Taiwanese Watson's Personal Care Stores. Universal Journal of Management, 3(5), 187-197. https://doi.org/10.13189/ujm.2015.030503

Leninkumar, V. (2017). The Relationship between Customer Satisfaction and Customer Trust on Customer Loyalty. International Journal of Academic Research in Business and Social Sciences, 7(4), 450. https://doi.org/10.6007/IJARBSS/v7-i4/2821

Liang, X., \& Zhang, S. (2009). Investigation of customer satisfaction in student food service. International Journal of Quality and Service Sciences, 1(1), 113-124. https://doi.org/10.1108/17566690910945903

Nurcahyo, S. R. B., \& Nurtjahjani, F. (2018). Pengaruh Brand Image dan Kualitas Pelayanan terhadap Loyalitas Pelanggan pada Wonderwash Laundry Malang. Jurnal Aplikasi Bisnis, 4(1), 21-25.

Oliver, R. L. (1999). Whence consumer loyalty? Journal of Marketing, 63(SUPPL.), 33-44. https://doi.org/10.2307/1252099

Parasuraman, A., Zeithaml, V. A., \& Berry, L. L. (1985). A Conceptual Model of Service Quality and Its Implications for Future Research. Journal of Marketing, 49(4), 41. https://doi.org/10.2307/1251430

Parasuraman, A., Zeithaml, V. A., \& Berry, L. L. (1988). SERVQUAL: A Multiple-Item Scale for Measuring Consumer Perceptions of Service Quality LEONARD L. BERRY. Journal of Retailing, 64, 12-37.

Purba, L. N. br, Wartiningsih, E., \& Susyanti, D. W. (2016). Pengaruh Kualitas Pelayanan Terhadap Kepuasan Pelanggan PT Global Knowledge. Epigram, 13(2). https://doi.org/10.32722/EPI.V13I2.817

Rashid, I. M. A., Rani, M. J. A., Yusuh, B. N. M., \& Shaari, M. S. (2015). International Journal of Information ,. International Journal of Information, Business and Management, 6(3), $189-190$. https://doi.org/10.1016/j.ijinfomgt.2010.11.002

Rauch, D. A., Collins, M. D., Nale, R. D., \& Barr, P. B. (2015). Measuring service quality in mid-scale hotels. International Journal of Contemporary Hospitality Management, 27(1), 87-106. https://doi.org/10.1108/IJCHM-06-2013-0254

Rusmawati, \& Marlindawaty. (2018). Analisis Kualitas Pelayanan, Harga, dan Promosi terhadap Kepuasan Pelanggan Laundry BJR Batakan Balikpapan. Jurnal Eksekutif, 15(1), 216-243. http://jurnal.ibmt.ac.id/index.php/jeksekutif

Saad Andaleeb, S., \& Conway, C. (2006). Customer satisfaction in the restaurant industry: An examination of the transaction-specific model. Journal of Services Marketing, 20(1), 3-11. https://doi.org/10.1108/08876040610646536

Seiders, K., Voss, G. B., Grewal, D., \& Godfrey, A. L. (2005). Do satisfied customers buy more.pdf. Journal of Marketing, 69(October), 26-43.

Sureshchandar, G. S., Rajendran, C., \& Anantharaman, R. N. (2002). Determinants of customer-perceived service quality: A confirmatory factor analysis approach. Journal of Services Marketing, 16(1), 9-34. https://doi.org/10.1108/08876040210419398

Wirtz, J., Chew, P., \& Lovelock, C. H. (2012). Essentials of Services Marketing, 2nd Edition. January, $197-223$. https://doi.org/10.1002/joe 
(C) 2021 by the authors; licensee Growing Science, Canada. This is an open access article distributed under the terms and conditions of the Creative Commons Attribution (CC-BY) license (http://creativecommons.org/licenses/by/4.0/). 